Article

\title{
Does the Level of Environmental Uncertainty Matter in the Effect of Returnee CEO on Innovation? Evidence from Panel Threshold Analysis
}

\author{
Weili Huang * $*$, Guangqi Ma and Xuemeng Chen \\ School of Economics and Management, Shaanxi University of Science and Technology, Shaanxi 710021, China; \\ maguangqi@sust.edu.cn (G.M.); 18292002066@163.com (X.C.) \\ * Correspondence: 18309292107@163.com
}

Received: 17 April 2019; Accepted: 4 May 2019; Published: 8 May 2019

check for updates

\begin{abstract}
This study applies a panel threshold regression model to reconcile the inconsistent findings about returnee chief executive officer (CEO) effects on enterprise innovation using the environmental uncertainty as the threshold variable and panel data from 187 publicly traded electronic firms in China for the period 2012-2016. The empirical results suggest that a significant double threshold effect does exist, showing an inverted-U correlation between returnee CEO and innovation. Specifically, a returnee $\mathrm{CEO}$ significantly promotes innovation at moderate levels of environmental uncertainty but significantly hinders innovation when the environmental uncertainty surpasses the larger threshold value, which contradicts much of the previous literature. This research enriches the scholarship on returnee CEOs and lays a theoretical foundation that firms can use in corporate governance. If firms pay more attention to environmental uncertainty while formulating new $\mathrm{CEO}$ introduction policies, substantial innovation ability can be improved at moderate levels of environmental uncertainty.
\end{abstract}

Keywords: returnee CEO; enterprise innovation; environmental uncertainty; threshold effect

\section{Introduction}

Returnees are skilled persons who study or work in metropole nations and subsequently return to their home country [1]. Domestic governments make great efforts to attract overseas talent due to their international capitalization advantages, such as technical and organizational knowledge, and networks absorbed [2]. China also launched a series of overseas-talent-attraction plans, such as the "Overseas High-Level Talent Introduction Program" to lure returnees [3]. Major achievements of these talent-attraction programs cannot be neglected. Statistics from the Education Service Center of the Ministry of Education show that more than three million international students chose to return to China as of 2017. These returnees played a much more crucial role in many fields [2], for instance, indigenous innovation [4]. Increasingly more companies are beginning to introduce returnees to participate in the board of directors. Some returnees even directly serve as the company's manager or chief executive officer (CEO).

With increased globalization [5], Chinese firms are in an increasingly uncertain economic environment. It is particularly important for a Chinese company to convert an idea into a business. As a decision-maker, a carrier of important technical knowledge, and a spark for indigenous innovation, a returnee CEO (hereafter, RCEO) plays a pivotal role in business innovation. Above all, it is valuable to study how an RCEO impacts the level of enterprise innovation in emerging markets from a micro level. Although there is growing research on the RCEO's effect on company innovation, there is no consensus on the relationship between RCEOs and company innovation. On the one hand, some studies argue that there is a significant association between RCEOs and company innovation [6-10]. 
Alternatively, one could argue that an RCEO has a non-significant effect $[1,11]$, or even a negative effect on innovation $[1,12,13]$. Such complexity suggests that there is a non-uniform effect of RCEOs on enterprise innovation and the pre-requisites conditioning enterprise innovation from RCEOs.

Scholars took a contingency perspective to reconcile these inconsistent findings about the impact of returnee executive and company innovation, using variables such as environmental uncertainty (hereafter, EU) as an underlying moderator of the association between RCEOs and enterprise innovation [14-17], but these studies also show mixed findings. For example, some studies document a positive effect from the interaction between policy-makers and EU on organizational innovation [18-21]. Alternatively, others show a negative effect from the interaction between CEOs and EU on firm performance $[13,22]$. These ambiguous findings about the relationship between RCEOs and company innovation delineate an important research gap in the field.

This study fills this gap by utilizing a panel threshold regression model to reconcile the nonlinear relationship between RCEOs and innovation using environmental uncertainty as the threshold variable. It should be noted that the main purpose of this paper is to investigate the threshold level above which the RCEO adversely affects innovation, using a threshold regression model. Simultaneously, we also investigate the optimal threshold interval at which the RCEO can have a positive association with innovation.

To address the research question, we use panel data from 187 publicly traded electronic firms in China for the period 2012-2016. Our empirical results suggest that a significant double threshold effect does exist, showing an inverted-U correlation between returnee CEO and innovation. Furthermore, our results are consistent with the position that the impact of returnee CEOs on innovation is positive and notably significant at moderate levels of environmental uncertainty. However, the returnee CEO exerts a significant and negative effect on innovation when the environmental uncertainty surpasses the larger threshold value

This paper makes three contributions by investigating why and when an RCEO has a discordant complex effect on enterprise innovation. Firstly, to advance the scientific understanding of the complex process of the RCEO-innovation nexus, we provide a nuanced explanation of why an RCEO can have both a positive and negative effect on enterprise innovation. Secondly, departing from prior research [21], this study delineates the boundary conditions between the positive and adverse effects of RCEOs by conjecturing that the responses of enterprise innovation to an RCEO could be different when gauged at various levels of EU, in an attempt to understand when the RCEO may have a positive or negative influence on enterprise innovation. Thirdly, unlike prior studies, which rely on linear specification where an RCEO indicator is simply interacting with a conditioning variable, this study uses nonlinear panel estimation techniques to assess EU (threshold variable). Specifically, we rely on panel threshold regression (PTR) methodology, developed by Hansen (1999).

The article is structured as follows: Section 2 reviews the related literature and develops the hypotheses. Section 3 introduces the panel threshold model and describes the sample data. Section 4 provides the results. Section 5 discusses the findings and explores their implications. Finally, Section 6 concludes and gives directions for future research

\section{Theoretical Analysis and Research Hypothesis}

\subsection{RCEO and Enterprise Innovation}

The concept of imprinting attracted interest from a broad range of areas-from organizational ecology to individual careers. The widespread use of the imprinting concept makes it possible to develop a general definition of imprinting theory, which highlights the lasting impact of previous history on individuals. Specifically, the definition of imprinting theory includes three key elements [23]: brief sensitive periods of transition during which the individuals or organizations exhibit high susceptibility to the external environment [23]; (2) a process whereby the individuals or organizations develop characteristics from experiences during sensitive periods; and (3) the persistence of imprints despite 
time passing and subsequent environmental changes [24]. In terms of this study, the CEO's experience in developed countries is an "imprinting" process. Namely, CEOs come to reflect elements of their environment during overseas work and study periods. The CEO's cognition and capability imprints persistently impact their decision-making and management behaviors of enterprise innovation even though they returned to China. According to imprinting theory, the impact of RCEOs on enterprise innovation is the combined effects of their advantages and disadvantages.

On the one hand, this assessment is consistent with the imprinting theory argument that prior history has an enduring impact on the individual. Hence, returnees are seen as an important mechanism for bridging knowledge gaps and for upgrading the technological capabilities of electronic firms in emerging economies when compared to their local counterparts. Firstly, returnee CEOs represent an important channel for international knowledge spillovers from developed countries [1], and their foreign knowledge contributes to domestic firm innovation, which may help firms actively explore innovation opportunities [25]. In addition, pursuing technological innovation is an activity with innately risky and uncertain characteristics. CEOs with international experience have enough valuable and rare abilities to deal with complex environments, uncertainty, and high risk $[9,13]$. Moreover, the RCEO's unique social capital advantage is conducive to reducing transaction costs and the time needed to build the company's capabilities when exploring innovation [26].

On the other hand, RCEOs also have potential disadvantages and may actually limit innovation performance [12]. Firstly, according to imprinting theory, having stayed abroad for a long period of time, RCEOs are imprinted with developed institutional environments, such as developed capital markets [27], higher informational efficiency levels [28], and strong intellectual property protection [23]. The imprinted experiences exert a persistent influence on CEOs and make it hard for them to re-adapt to the underdeveloped institutional environment [12]. The RCEO's initially learned responses or knowledge sets are disadvantageous in Chinese distinct regulatory and normative institutional environments, which may constrain the RCEO's appropriation of identifying innovation opportunities and management skills. RCEOs lack local knowledge and home-based social networks, even though they have advanced knowledge and experience accumulated in relatively developed countries [29]. Secondly, after many years, RCEOs may face great challenges in building local connections and maintaining old contacts (Butcher, 2002; Qin, 2007), which represent crucial channels for accessing scare information and resources [30] when operating in weak situations. Thirdly, RCEOs need to take time to understand domestic markets, society, and how to conduct business during the new sensitive period when they operate in China [31].

\subsection{Threshold Effect of Environmental Uncertainty}

Such complexity suggests the existence of the RCEO's non-uniform effect on enterprise innovation and the pre-requisites conditioning enterprise innovation. Scholars took a contingency perspective to reconcile these inconsistent findings about the impact of returnee executive and company innovation, using variables such as environmental uncertainty as an underlying moderator of the association between RCEOs and company innovation.

EU refers to the rapidly changing markets [32] and is usually associated with high risk, high ambiguity [33], and a lack of information, which makes it difficult for RCEOs to assess means-ends relationships, analyze and understand strategy [34], allocate resources for innovation [35], and confidently assign probabilities to their outcomes [15]. According to upper echelons theory, the more unstable, risky, or crisis-laden the decision-making situation is, the more likely it is that RCEOs will bear the stress. Hence, RCEOs are more motivated to make sense of environmental cues, interpret relevant information, and change crises into opportunity [19]. According to imprinting theory, CEOs with advanced management skills are better prepared to deal with turbulent environments by executing innovation strategies to achieve superior innovation performance [15].

However, a high degree of environmental dynamism might reduce the likelihood of the RCEO's strategic orientation to engage in enterprise innovation [13]. According to the resource-based 
perspective, in situations with high instability of environmental change, achieving innovation performance takes longer. As such, the RCEO may select a short-term plan that is an effective use of the firm's limited resources to obtain the benefit as soon as possible [36]. Consequently, when EU is above a certain level, the RCEO cannot fully increase innovation performance due to constrained information. When EU reaches a certain level (i.e., a threshold), the effects of the RCEO on enterprise innovation will become significant and positive due to the effective use of prior experience, limited resource, and information.

In view of the inconclusive findings provided by previous studies, the aim of this paper is to revisit threshold effects in the RCEO-innovation nexus. We use the panel threshold regression approach and reassess whether the RCEO's effects depend on the level of EU.

\section{Study Design}

In this section, to demonstrate that the panel threshold regression technique is a more appropriate testing approach, the linear regression model is firstly employed. Studies of the sensitivity of enterprise innovation (Innovat) to an RCEO (Ceosea) under environmental uncertainty $(E u)$ typically employ the following regression:

$$
\text { Innovat }_{\text {it }}=\mu_{i}+\beta_{1} \text { Ceosea }_{i t-1}+\beta_{2} \text { Eu }_{i t-1}+\beta_{3} \text { Ceosea }_{i t-1} * E u_{i t-1}+\alpha \sum C V_{i t-1}+\varepsilon_{i t},
$$

where subscript $i$ represents the $i$ th firm and $t$ denotes the $t$ th period; Innovat is the number of patents; Ceosea is a dummy variable that is equal to one if the CEO is a returnee from overseas and zero otherwise; $E u$ is coefficient of variation of sales, standing proxy for variability in the organization's external environment; and $C V$ represents a series of control variables.

The coefficient $\left(\beta_{3}\right)$ on Ceosea $a_{i t-1} * E u_{i t-1}$, indicates the sensitivity of enterprise innovation to an RCEO under EU. A significant $\beta_{3}$ implies that enterprise innovation is sensitive to the RCEO under EU, whereas a statistically insignificant $\beta_{3}$ implies it is not sensitive. However, since our study is based on the hypothesis that the RCEO will impact enterprise innovation in a nonlinear way, on the basis of Equation [23], we further adopt a nonlinear analysis tool to study the RCEO's impact on enterprise innovation by specifically using the Hansen panel threshold regression analysis (PTR) with EU as the threshold variable [37].

\subsection{Panel Threshold Regressions}

To avoid error from the artificial EU division interval, we use the Hansen PTR to internally divide the EU $\left(q_{i t}=E u_{i t}\right)$ interval according to data characteristics. Then, the influence mechanism of the $\operatorname{RCEO}\left(z_{i t}=\right.$ Ceosea $\left._{i t}\right)$ on enterprise innovation $\left(y_{i t}=\right.$ Innovat $\left._{i t}\right)$ for different intervals is examined by firstly considering a single-threshold regression model as a special case of the panel threshold model, which takes the following form:

$$
y_{\text {it }}=\mu_{\mathrm{i}}+\beta_{1} z_{i t} I\left(q_{i t} \leq \gamma\right)+\beta_{2} z_{i t} I\left(q_{i t}>\gamma\right)+\varepsilon_{i t}
$$

where subscripts $\mathrm{i}=1, \ldots, \mathrm{N}$ index the firm and the subscript $t=1, \ldots, \mathrm{T}$ represents time; $q_{i t}$ indexes the threshold variable, standing proxy for $\mathrm{EU} ; \gamma$ is the threshold value; the indicator function $I(\cdot)$ is equal to 0 when $q_{i t} \leq \gamma$ and 1 in the other case; $y_{i t}$ is Innovat $t_{i t} ; z_{i t}$ represents an m-vector of explanatory variables; the slope coefficient $\beta_{1}$ represents the parameter vector of the regression in a low-uncertainty regime; and $\beta_{2}$ represents the corresponding parameter vector in a high-uncertainty regime. $\mu_{\mathrm{i}}$ is the firm-specific fixed effect and the random variable, and $\varepsilon_{i t}$ is the regression error term.

As in Hansen [37], at the first step, removing the individual specific effects by "mean differencing" yields the model in Equation. At the second step, the threshold parameter, $\hat{\gamma}$, is estimated by minimizing 
the concentrated sum of square errors (the residual vector is $\hat{\varepsilon}^{*}=\hat{\varepsilon}^{*}(\hat{\gamma})$ ). Once $\hat{\gamma}$ is identified, the slope coefficient estimates, $\hat{\beta}$, can be obtained [37].

$$
y_{\mathrm{it}}^{*}=\beta z_{i t}^{*}(\gamma)+\varepsilon_{i t}^{*}
$$

where * represents variables deviated from the group mean.

Two tests are then performed: a test of the significance of the threshold effect and a test of whether the threshold estimation value is equal to the true value. Firstly, an F-stat test under the null hypothesis of no threshold effect $\left(H_{0}: \beta_{1}=\beta_{2}\right)$ is used to determine if there exists a threshold effect, and a "bootstrap" method is used to simulate the asymptotic distribution of the likelihood ratio statistic $\mathrm{F}(\gamma)$ [37], such that

$$
\mathrm{F}(\gamma)=\frac{S S E_{0}-S S E_{1}(\hat{\gamma})}{\hat{\delta}^{2}},
$$

where $S S E_{0}$ and $S S E_{1}$ are the residual sum of squares under $H_{0}$ and $H_{1}$, respectively; $\hat{\sigma}^{2}$ is the residual variance under $H_{1}$.

The null hypothesis of no threshold effect is rejected if the asymptotic $p$-value for $\mathrm{F}(\gamma)$ under $H_{0}$ constructed from the bootstrap is smaller than the desired critical value (e.g., $5 \%$ ).

Secondly, when there is a threshold effect, the next interesting question is whether or not the threshold parameter $\hat{\gamma}$ is consistent with the true value of $\gamma$. Since $\gamma$ is not identified under $H_{0}$, the asymptotic distribution is not standard, and the best way to form confidence intervals for $\gamma$ is to form "no-rejection region" using a "bootstrap" method to simulate the likelihood ratio statistic for tests on $\gamma$. The null hypothesis is rejected when the likelihood ratio statistic value is too large and the $p$-value is less than the desired critical value (e.g., 5\%) [38].

Then, if all tests are passed, the above steps can be repeated to test two or multiple threshold effects. In our study, we start by considering the double-threshold regression model, which is expressed as follows:

$$
\begin{aligned}
& \text { Innovat }_{i t}=\mu_{i}+\beta_{1} \text { Ceosea }_{i t} I\left(\text { Eu }_{i t} \leq \gamma_{1}\right)+\beta_{2} \text { Ceosea }_{i t} I\left(\gamma_{1}<E u_{i t} \leq \gamma_{2}\right) \\
& +\beta_{3} \text { Ceosea }_{i t} I\left(\gamma_{2}<E u_{i t}\right)+\alpha \sum C V_{i t}+\varepsilon_{i t}
\end{aligned} .
$$

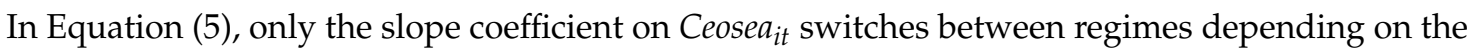
value of an observable threshold variable $E u_{i t}$, while the slope coefficients on the other control variables are constrained to remain invariant [39]. In this way, we isolate the variable of interest and concentrate the analysis on the contingency effects in the relationship between the RCEO and enterprise innovation. The innovation-enhancing or -debasing effects of the RCEO will vary with the threshold condition.

\subsection{Variable Measurement}

\subsubsection{Dependent Variable}

The indicator commonly used to characterize the enterprise innovation level is patent application quantity [40]. The number of patent applications is a relatively good proxy for innovation capability because it reflects a better proxy for innovative output [41].

\subsubsection{Independent Variable}

As in Yuan and Wen [25], in our study, RCEO is constructed as a dummy variable, which is equal to 1 if the CEO is a returnee from overseas in year $t$, and 0 otherwise.

\subsubsection{Threshold Variable}

The key elements in a firm's external environment are customers, competitors, government regulations, and the labor market [42]. A firm's market characteristic can be parsimoniously 
characterized by the coefficient of variation of sales (CVS) [32,43]. The CVS is calculated over a five-year period (e.g. 2012-2016). Specifically, the coefficient of variation for sales is calculated as

$$
\operatorname{CVS}\left(Z_{i t}\right)=\frac{\sqrt{\sum_{t=1}^{n} \frac{\left(z_{i t}-\bar{z}\right)^{2}}{n}}}{\bar{z}},
$$

where $Z_{i t}$ is the market uncertainty for firm $i$ in year $t$, which is the residual of the model (7); $\bar{z}$ represents the five-year mean; in this case, $\mathrm{n}$ means five years.

$$
\text { Sale }_{i t}=\alpha_{0}+\alpha_{1} \text { Year }+\varepsilon_{i t},
$$

where Sale $_{i t}$ is the sale revenue of firm $i$ in year $t$; Year is an ordinal categorical variable, and, in our analysis, Year is equal to 1 if $t$ is 2016, Year is equal to 2 if $t$ is 2015, . , and Year is equal to 5 if $t$ is 2012.

To mitigate industry effects, the CVS from previous steps is normalized by dividing it by the uncertainty measure for that firm's two-digit SITC code over 2012-2016, yielding the "final" firm-specific proxy for EU.

\subsubsection{Control Variables}

Following prior studies, such as Chen, Sharma, Zhan, and Liu [13], Haider et al. [44], Kieschnick and Moussawi [45], and Francis et al. [46], we control a variety of board and firm characteristics that may affect innovation capability in our regressions. For firm characteristics, we include firm age (Age), firm ownership (Nature), research and development staff (Rdstaff), asset-liability ratio (Alr), liquidity ratio $(\mathrm{Al})$, and shareholding ratio of the largest shareholder (Concen). For board characteristics, we include board size (Mtbgm), board average age (Tmtage), and returnee executive size (Sumforeitm), In addition, as the CEO's demographic characteristics reflect their cognitive mode and value [47], which may influence their decision behaviors, we include CEO ownership (CEOshare), CEO gender (CEOgender), and CEO duality (CEOduab). The details of variable construction are shown in Appendix A.

\subsection{Sample}

The empirical analysis uses all firms from electronic industry that were listed on the Shanghai and Shenzhen Stock Exchange (A) spanning the period 2012 to 2016 as our initial sample. Companies in the electronic industry are typical for this empirical analysis due to their inherent strong attraction to the returnee. We use annual accounting and board characteristics data from the Wind database and China Security Market and Accounting Research (CSMAR) database. Consistent with prior research, for a firm/year to be included in the sample, it must satisfy the following requirements: (i) non-missing comparability measures, (ii) non-missing firm and board characteristics, and (iii) a balanced panel data for the threshold regression model (Hansen 2000). The final balanced panel dataset covers 187 listed firms and 935 observations during 2012-2016, the detailed information can be shown in Supplementary Materials. We further winsorize all continuous variables at the top and bottom one percentile to eliminate the undue influence of outliers. STATA version 14.0 was used for calculation and analyses.

\section{Empirical Research}

We used the panel threshold model to analyze the possible asymmetric nonlinear relationship between the RCEO and innovation using EU as the threshold variable. Enterprise innovation ability was the explained variable, RCEO was the core explaining variable, and EU was the threshold variable. Simultaneously, we used a one-year time lag for our independent variable to reduce endogeneity problems. 


\subsection{Unit Root Tests}

Before proceeding to the threshold regression, the time series properties of all variables were checked through the Harris and Tzavalis panel unit root procedures [48]. For this test, the null hypothesis is that there is a unit root [49]. The results in Table 1 reveal that nonstationarity cannot be rejected just in the cases of Patent, Ceosea, Ceogender, Ceoshare, and Sumforeitm. However, the five cases become stationary in their first logarithmic differences at any conventional level.

Table 1. Panel unit root test.

\begin{tabular}{cccc}
\hline Variable & Statistic & $\mathbf{z}$ & $p$-Value \\
\hline Patent & 0.686 & 5.205 & 1.000 \\
$\Delta$ Patent & -0.234 & -15.001 & 0.000 \\
Ceosea & 0.630 & 3.636 & 0.999 \\
$\Delta$ Ceosea & -0.500 & -21.293 & 0.000 \\
EU & 0.000 & -14.030 & 0.000 \\
Ceogender & 0.500 & 0.000 & 0.500 \\
$\Delta$ Ceogender & -0.500 & -21.283 & 0.000 \\
Ceoshare & 0.592 & 2.571 & 0.995 \\
$\Delta$ Ceoshare & -0.488 & -21.001 & 0.000 \\
Ceoduab & 0.259 & -6.742 & 0.000 \\
Sumforeitm & 0.457 & -1.198 & 0.116 \\
$\Delta$ Sumforeitm & -0.267 & -15.779 & 0.000 \\
Mtbgm & 0.281 & -6.141 & 0.000 \\
Tmtage & 0.344 & -4.384 & 0.000 \\
Rdstaff & 0.066 & -12.192 & 0.000 \\
Concen & 0.435 & -1.816 & 0.035 \\
Age & 0.000 & -14.030 & 0.000 \\
Nature & 0.403 & -2.721 & 0.003 \\
Alr & 0.186 & -8.826 & 0.000 \\
Al & 0.360 & -3.918 & 0.000
\end{tabular}

Notes: HT is the Harris and Tzavalis test for a unit root in the model. $\left(^{* * *}\right)$ signifies rejection of the unit root hypothesis at the $1 \%$ level. See Table A1 (Appendix A) for variable definitions.

\subsection{Threshold Effect Test}

The threshold effect was tested first. Recall that there are two tests, F and LR, where the former examines the significance of the threshold effect and the latter examines whether the threshold estimation value is equal to the true value. The two tests results are presented in Table 2.

Table 2. Tests for threshold effects and threshold estimates.

\begin{tabular}{|c|c|c|c|c|c|c|c|}
\hline \multirow{2}{*}{ Model } & \multirow{2}{*}{ F-Value } & \multirow{2}{*}{$p$-Value } & \multicolumn{3}{|c|}{ Critical Value } & \multirow{2}{*}{$\begin{array}{c}\text { Threshold } \\
\text { Value }\end{array}$} & \multirow{2}{*}{$\begin{array}{c}\text { Confidence } \\
\text { Interval }\end{array}$} \\
\hline & & & $1 \%$ & $5 \%$ & $10 \%$ & & \\
\hline Single Threshold & 0.817 & 0.072 & 7.488 & 4.342 & 2.902 & 0.283 & $0.145-3.561$ \\
\hline Double Threshold & 3.445 & 0.059 & 5.992 & 3.675 & 2.666 & 0.697 & $0.559-3.561$ \\
\hline Triple Threshold & 0.286 & 0.600 & 6.381 & 3.356 & 2.520 & & \\
\hline
\end{tabular}

Note: F-statistics and $p$-values are from repeating the bootstrap procedures 1000 times.

The $p$-values of the single, double, and triple threshold models were $0.072,0.059$, and 0.600 , respectively. The threshold effect was significant for the single- and double-threshold model, at a significance level of 0.10 for both. The results reveal two threshold estimation values of EU, 0.283 and 0.697. Hence, a detailed analysis of the double-threshold model is provided. For the double-threshold model, there are three regimes, referred to as low-, moderate-, and high-uncertainty levels, and their EUs fall within the ranges $0-0.283$ and $0.283-0.697$, and exceed 0.697 , respectively.

Once the thresholds were obtained, their confidence intervals were then examined to check whether the threshold of the EU estimate was equal to the real value. As discussed earlier, this can 
be achieved by computing the likelihood ratio test. ( $a, b$ plot the confidence intervals for the first and second thresholds, respectively. The EU is the threshold estimation value when the LR value is 0 . As presented in $(a, b$, the corresponding threshold parameters of the EU were 0.283 and 0.697, respectively (see the value in the axis of Figure $1 \mathrm{a}, \mathrm{b}$ ). The confidence interval of the threshold estimation value was the interval of $\mathrm{EU}$, which was less than $\mathrm{LR}=7.3523$ when the confidence interval was $95 \%$. Hence, the $95 \%$ confidence intervals of the threshold estimation values 0.283 and 0.697 were 0.145-3.561 and 0.559-3.561, respectively. As the two threshold estimation values were contained in the corresponding confidence interval, the threshold of the EU estimate was equal to the real value [50].

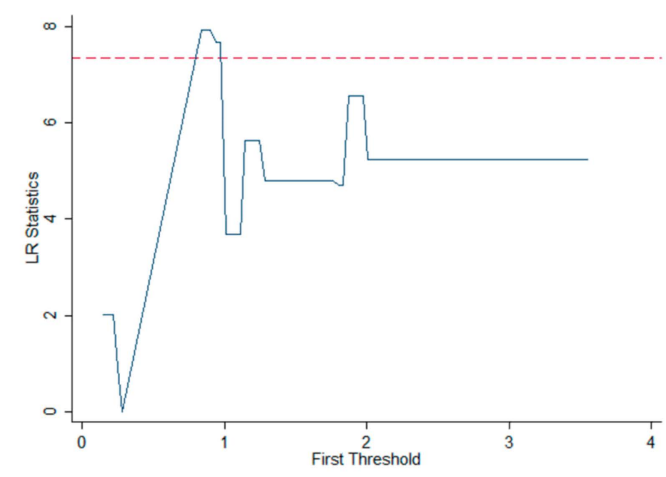

(a)

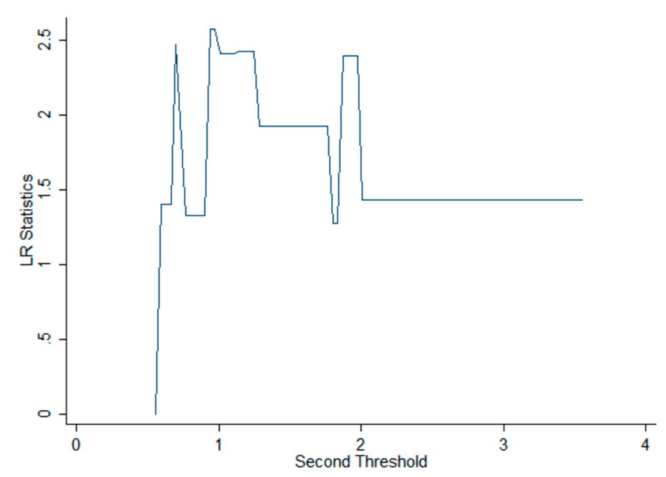

(b)

Figure 1. Confidence interval for the threshold. (a) First threshold in the two-threshold model;

(b) second threshold in the two-threshold model.

\subsection{Main Results}

Table 3 reports the estimated results from the linear regression model and the panel threshold regression model. To better illustrate the nonlinear size of $\mathrm{EU}$, we firstly estimated the fixed-effect model, a linear regression modeland found that RCEO was positive and significantly $(\beta=149.5, p<0.01$ ) associated with enterprise innovation, as shown in Model 1 of Table 3. However, EU negatively moderated the effect of the RCEO on enterprise innovation.

We turn now to the results of the estimation of the panel threshold model. Model 2 in Table 3 represents the regression slope estimates for the three regimes, which were distinguished by different regression slopes. In regime 1 , where the EU was below 0.283 , the estimate of the RCEO coefficient was positive, but insignificant $(\beta=1.219, p>0.1$ ). In regime 2 , where the EU was between 0.283 and 0.697 , the estimated coefficient was significantly positive $(\beta=72.070)$ at the level of $1 \%$. In regime 3 , where the EU was above 0.697 , the estimate of RCEO coefficient was positive $(\beta=8.664)$, but insignificant.

As the larger threshold value was smaller than the mean $(0.697<1.428)$, we further divided the last regime into two regimes $(0.697<\mathrm{EU}<1.428$; EU $>1.428)$. By doing so, we could investigate why the coefficient on RCEO was insignificant when EU exceeded the larger threshold value.

Table 3. FE and threshold regression estimate of Equation (5).

\begin{tabular}{cccc}
\hline Variables & $\begin{array}{c}\text { Model 1 (Without } \\
\text { Threshold Effects) }\end{array}$ & Variables & $\begin{array}{c}\text { Model 2 (With } \\
\text { Threshold Effects) }\end{array}$ \\
\hline Ceosea & $149.5^{* * *}$ & Low regime & 1.219 \\
& $(50.76)$ & $($ EU $\ll 0.283)$ & $(0.135)$ \\
EU & -25.33 & Moderate regime & $72.070^{* * *}$ \\
& $(21.75)$ & $(0.283<$ EU $<0.697)$ & $(3.999)$ \\
Ceosea $\times E U$ & $-60.61^{*}$ & High regime & 8.664 \\
& $(33.62)$ & $($ EU $\gg 0.697)$ & $(1.031)$ \\
\hline
\end{tabular}


Table 3. Cont.

\begin{tabular}{|c|c|c|c|}
\hline Variables & $\begin{array}{l}\text { Model } 1 \text { (Without } \\
\text { Threshold Effects) }\end{array}$ & Variables & $\begin{array}{c}\text { Model } 2 \text { (With } \\
\text { Threshold Effects) }\end{array}$ \\
\hline L1. Ceogender & $\begin{array}{c}108.4 \\
(85.25)\end{array}$ & L1. Ceogender & $\begin{array}{l}-4.676 \\
(-0.167)\end{array}$ \\
\hline L1. Ceoshare & $\begin{array}{l}-0.000 \\
(0.000)\end{array}$ & L1. Ceoshare & $\begin{array}{l}0.000^{* * *} \\
(2.895)\end{array}$ \\
\hline L1. Ceoduab & $\begin{array}{c}31.20 \\
(31.53)\end{array}$ & L1. Ceoduab & $\begin{array}{c}2.633 \\
(1.452)\end{array}$ \\
\hline L1. Sumforeitm & $\begin{array}{l}16.64^{* *} \\
(8.105)\end{array}$ & L1. Sumforeitm & $\begin{array}{c}13.319 * * \\
(2.263)\end{array}$ \\
\hline L1. Mtbgm & $\begin{array}{c}2.843 \\
(8.058)\end{array}$ & L1. Mtbgm & $\begin{array}{c}-0.299 \\
(-0.158)\end{array}$ \\
\hline L1. Tmtage & $\begin{array}{l}-0.512 \\
(4.745)\end{array}$ & L1. Tmtage & $\begin{array}{c}-1.632 \\
(-1.538)\end{array}$ \\
\hline L1. Rdstaff & $\begin{array}{c}0.374 \\
(0.770)\end{array}$ & L1. Rdstaff & $\begin{array}{l}-0.204 \\
(-1.011)\end{array}$ \\
\hline L1. Concen & $\begin{array}{l}-0.469 \\
(1.149)\end{array}$ & L1. Concen & $\begin{array}{l}-0.3475 \\
(-1.189)\end{array}$ \\
\hline L1. Age & $\begin{array}{c}16.56^{* * *} \\
(4.109)\end{array}$ & L1. Age & $\begin{array}{l}12.156^{* * * *} \\
(11.712)\end{array}$ \\
\hline L1. Nature & $\begin{array}{l}-16.39 \\
(53.37)\end{array}$ & L1. Nature & $\begin{array}{l}21.950 \\
(1.463)\end{array}$ \\
\hline L1. Alr & $\begin{array}{l}1.954^{* *} \\
(0.936)\end{array}$ & L1. Alr & $\begin{array}{c}0.174 \\
(0.897)\end{array}$ \\
\hline L1. $A l$ & $\begin{array}{l}1.185 * \\
(0.609)\end{array}$ & L1. $A l$ & $\begin{array}{l}-0.116 \\
(-0.875)\end{array}$ \\
\hline Observations & 935 & Observations & 935 \\
\hline
\end{tabular}

Note: ${ }^{* * *}, * *$, and ${ }^{*}$ indicate significance at the 1,5 , and $10 \%$ levels, respectively. Standard errors are in parentheses.

\subsection{Further Research}

Table 4 presents the estimation results when the last regime was divided into two regimes. Consistent with our expectations, in Model 1, we found the estimated new coefficient on RCEO was still insignificant when the EU was between 0.697 and 1.428. However, in Model 2, the coefficient on RCEO was significant and negative $(\beta=-13.321, p<0.1)$ when EU exceeded 1.428. In sum, the results presented in suggested that any relationship at higher levels was either insignificant or notably negative. This means that the RCEO-innovation nexus in the case of China experiences threshold effects and asymmetries, challenging the widespread belief in the field of EU that the ongoing build-up of external environmental instability clearly threatens the effect of RCEO knowledge spillovers. Hence, on average, the net effect of RCEOs relative to their local counterparts on enterprise innovation was negative in high environmental dynamism - their disadvantages outweighed the advantages.

Over all, the results presented in, together with the significant and positive coefficient on RCEO in the second regime, lend credence to our hypothesis that the RCEO has a positive relationship with enterprise innovation in the moderate-uncertainty leverage regime but a negative relationship in the higher-uncertainty leverage regime. The findings are also in line with the emerging empirical evidence of the RCEO's non-monotonic relationship with enterprise innovation.

Table 4. Divided regimes regression estimation results.

\begin{tabular}{ccc}
\hline Variables & Model1 $(0.697<E U<1.428)$ & Model2 $(E U>1.428)$ \\
\hline Ceosea & 4.563 & $-13.321^{*}$ \\
& $(15.92)$ & $(7.848)$ \\
L1. Ceogender & $-63.93^{*}$ & 3.049 \\
& $(36.97)$ & $(15.86)$ \\
\hline
\end{tabular}


Table 4. Cont.

\begin{tabular}{ccc}
\hline Variables & Model1 $(0.697<E U<1.428)$ & Model2 $(E U>1.428)$ \\
\hline L1. Ceoshare & $-1.71 \mathrm{E}-8$ & $7.66 \mathrm{E}-10$ \\
& $(1.84 \mathrm{E}-7)$ & $(7.06 \mathrm{E}-8)$ \\
L1. Ceoduab & 15.53 & -2.897 \\
& $(11.57)$ & $(10.84)$ \\
L1. Sumforeitm & 3.529 & 3.261 \\
& $(5.338)$ & $(2.049)$ \\
L1. Mtbgm & $-7.534^{*}$ & -1.809 \\
& $(3.933)$ & $(1.749)$ \\
L1. Tmtage & 2.129 & 1.452 \\
& $(2.541)$ & $(1.027)$ \\
L1. Rdstaff & 0.159 & $0.327^{* *}$ \\
& $(0.332)$ & $(0.162)$ \\
L1. Concen & -0.022 & -0.186 \\
& $(0.637)$ & $(0.211)$ \\
L1. Age & $9.410 * * *$ & 0.412 \\
& $(2.296)$ & $(0.525)$ \\
L1. Nature & 0.746 & $20.18^{* *}$ \\
L1. Alr & $(18.43)$ & $(9.562)$ \\
& -0.610 & -0.305 \\
L1. Al & $(0.405)$ & $(0.239)$ \\
& $-0.505^{*}$ & $-0.537^{* * *}$ \\
Observations & $(0.291)$ & $(0.159)$ \\
\end{tabular}

Notes: significance at $10 \%, 5 \%$, and $1 \%$ levels is denoted by $* * *$, and $* * *$, respectively. Standard errors are in parentheses.

\section{Robustness}

An alternative measure of enterprise innovation was used to increase the robustness of the results. We measured firm innovation with net profit margin on sales [51], as it can reflect the quality of innovation.

According to Table 5, the results of the F-test and $p$-value show that the null hypothesis of threshold effect test of EU was rejected at the $1 \%$ statistical level only in the double-threshold model, showing that the RCEO-innovation model is a double-threshold model. The threshold values were 1.284 and 2.008. In addition, the $95 \%$ confidence intervals of the threshold estimation values 1.284 and 2.008 were $1.284-2.008$ and 2.008-3.561, respectively.

Table 5. Tests for threshold effects and threshold estimates.

\begin{tabular}{|c|c|c|c|c|c|c|c|}
\hline \multirow{2}{*}{ Model } & \multirow{2}{*}{ F-Value } & \multirow{2}{*}{$p$-Value } & \multicolumn{3}{|c|}{ Critical Value } & \multirow{2}{*}{$\begin{array}{c}\text { Threshold } \\
\text { Value }\end{array}$} & \multirow{2}{*}{$\begin{array}{l}\text { Confidence } \\
\text { Interval }\end{array}$} \\
\hline & & & $1 \%$ & $5 \%$ & $10 \%$ & & \\
\hline Single Threshold & 1.987 & 0.147 & 2.414 & 3.745 & 7.237 & 1.284 & $1.284-2.008$ \\
\hline Double Threshold & 7.580 & 0.009 & 2.395 & 3.729 & 7.481 & 2.008 & $2.008-3.561$ \\
\hline Triple Threshold & 0.378 & 0.521 & 3.128 & 4.263 & 8.255 & & \\
\hline
\end{tabular}

Note: F-statistics and $p$-values are from repeating the bootstrap procedures 1000 times.

Table 6 reports the effect of RCEO on innovation (net profit margin on sales) in the threshold model. If EU is less than 1.284 (regime 1), a 1\% increase in RCEO may significantly contribute to a $0.938 \%$ increase in innovation. If EU is above 1.284 and below 2.008 in Regime 2, a 1\% increase in RCEO may significantly lead to an $11.253 \%$ increase in innovation at the $1 \%$ statistical level. If EU exceeds 2.008 in Regime 3, a 1\% increase in RCEO can bring about a 3.341\% decrease in innovation at the $1 \%$ statistical level. The results of this robustness test using an alternative measure of enterprise innovation were similar and suggested the same conclusion. 
Table 6. The effect of returnee chief executive officer (RCEO) on innovation in the threshold model.

\begin{tabular}{|c|c|}
\hline Variables & Threshold Effects \\
\hline Low regime & 0.938 * \\
\hline$(E U \ll 1.284)$ & $(0.544)$ \\
\hline Moderate regime & $11.253^{* * *}$ \\
\hline$(1.284<E U<2.008)$ & $(2.152)$ \\
\hline High regime & $-3.341^{* *}$ \\
\hline$(E U \gg 2.008)$ & $(1.492)$ \\
\hline L1. Ceogender & 2.123 \\
\hline & $(1.836)$ \\
\hline L1. Ceoshare & $\begin{array}{c}0.000 * * * \\
(0.000)\end{array}$ \\
\hline L1. Ceoduab & $\begin{array}{c}0.550 \\
(0.776)\end{array}$ \\
\hline L1. Sumforeitm & $\begin{array}{c}0.106 * * \\
(0.183)\end{array}$ \\
\hline L1. Mtbgm & $\begin{array}{c}0.065 \\
(0.047)\end{array}$ \\
\hline L1. Tmtage & $\begin{array}{c}0.005 \\
(0.117)\end{array}$ \\
\hline L1. Rdstaff & $\begin{array}{c}0.029 \\
(0.019)\end{array}$ \\
\hline L1. Concen & $\begin{array}{c}0.084^{* * *} \\
(0.032)\end{array}$ \\
\hline L1. Age & $\begin{array}{c}-0.582^{* * *} \\
(0.119)\end{array}$ \\
\hline L1. Nature & $\begin{array}{l}-0.084 \\
(1.246)\end{array}$ \\
\hline L1. Alr & $\begin{array}{c}0.005 \\
(0.025)\end{array}$ \\
\hline L1. $A l$ & $\begin{array}{c}0.081^{* * *} \\
(0.014)\end{array}$ \\
\hline Observations & 935 \\
\hline
\end{tabular}

Notes: significance at $10 \%, 5 \%$, and $1 \%$ levels is denoted by $* * *$, and $* * *$, respectively. Standard errors are in parentheses.

\section{Discussion}

There are valuable, theoretical, and practical policy implications that emerge from the empirical results [52], from which scholars and managers can considerably benefit.

\subsection{Theoretical Contributions}

This study aimed to explain the conflicting findings about the impact of an RCEO on enterprise innovation by examining the complex mechanism of the RCEO on firm innovation and investigating why and when an RCEO might benefit or hamper firm innovation. This study shows the mechanism via which an RCEO has a positive and a negative effect on firm innovation. An RCEO has a positive effect on enterprise innovation when firms operate in the environment with moderate uncertainty but a negative effect on enterprise innovation when firms operate in the environment with high uncertainty.

By investigating the complex mechanisms and contingencies of RCEOs on firm innovation, this study makes three incremental contributions to the RCEO literature. Firstly, this study extends the knowledge on the dual roles of RCEOs from a nonlinear perspective, thus providing a complete understanding of the positive and negative effects of firm innovation. Over the past few decades, the study of RCEOs attracted significant attention from different research fields [53-60]. However, the majority of research focuses on the linear relationship between RCEOs and innovation while neglecting the nonlinear effect of RCEOs on innovation, leaving an incomplete picture of the RCEO's role. 
Secondly, by categorizing environmental uncertainty into three regimes and comparing their different implications, this study helps reconcile conflicting findings about the threshold effect of environmental uncertainty on the link between RCEOs and firm innovation. Our findings show that the RCEO has a positive effect on innovation when firms operate in an environment with moderate uncertainty, while also has a negative effect on innovation when firms operate in the environment with high uncertainty, thus explaining why previous studies generated inconsistent findings on the moderating role of environmental uncertainty.

Thirdly, we measured firm innovation with patent application quantity as it can reflect the quantity of innovation. We also measured firm innovation with net profit margin on sales as it can reflect the quality of innovation. Our findings are robust to using net profit margin on sales yields as alternative measures of patent application quantity.

Finally, our findings further deepened the imprinting theory by exploring the interaction between a CEO's overseas experience and the current environment in which they operate.

\subsection{Managerial Implications}

Our study has some important implications for firms and policy-makers in emerging countries. Firstly, our findings show that firms place too much stress on a CEO's overseas experience but neglect their external environment, which might expose the firm to potentially lower innovation performance. Therefore, when designing the programs, CEO recruitment and training programs should consider the beneficial and detrimental roles of the returnee, especially in turbulent environments.

Secondly, our findings reveal that RCEOs should also be like contingent CEOs, and their behavior should align with the firm's environmental uncertainties. In other words, we recommend that RCEOs should adjust their behavior to better adapt to the prevailing environment faced by their firms. In addition, training programs could be provided to help RCEOs change their behavior, with continuous direction toward the changing trends in technology and customer market.

Thirdly, there should be a series of policies to mitigate the potentially harmful effect of RCEOs. Our study suggests that governments should build some appropriate social network platforms to help returnees develop business communities and political capital in their local countries, as well as obtain local market knowledge. Doing so can allow RCEOs to overcome their disadvantages in organization innovation activities.

\section{Conclusions}

Prior literature that examines the effect of returnee CEOs on enterprise innovation in turbulent environments mainly uses linear models and achieves complex results. Conversely, this paper uses a nonlinear model to study the relationship between RCEOs and innovation using environmental uncertainty as the threshold variable.

We use a panel threshold model to examine the threshold effect of the RCEO on enterprise innovation based on firm leverage panel data from 187 publicly traded electronic firms in China for the period 2012-2016. There are three primary conclusions: (i) on balance, the RCEO has a significant and positive effect on firm innovation. This finding supports our argument that the RCEO has advantages in terms of advanced knowledge and management experience from developed countries, and disadvantages in terms of a lack of business community and political capital in their local countries, and limited local market knowledge. What is more, their advantages outweigh the disadvantages; (ii) the double threshold effect of the RCEO on enterprise innovation is significant, and the consistencies of the threshold estimation value and the threshold real value are tested using the LR function diagram; (iii) the empirical results show an inverted-U correlation between returnee $\mathrm{CEO}$ and innovation. Specifically, the returnee CEO significantly promotes innovation at moderate levels of environmental uncertainty, whereas any relationship at higher levels is either insignificant or notably negative. 
The above findings can explain why and when an RCEO has the discordant complex effect on enterprise innovation. Moreover, our findings offer important implications for firms and policy-makers operating in emerging economies.

\section{Limitations and Future Research Directions}

This study involved certain limitations that require consideration. Firstly, the variables used in this study do not exhaust all variables in a fully developed supply-side model. To address this concern, it could be beneficial for researchers to include additional variables such as financial constraint and the geographies of marketization in future studies.

Secondly, we selected environmental uncertainty as one threshold variable to explain the complex mechanism of the RCEO on firm innovation, but there may be other contingency variables that could moderate this relationship, and they deserve further investigation in the future.

Thirdly, our empirical results were derived from a sample of electronic firms in China, thus raising concern about the universality for other emerging economies. Hence, future research is necessary to test the validity of the hypothesis in other countries.

Supplementary Materials: The following are available online at http://www.mdpi.com/2071-1050/11/9/2645/s1.

Author Contributions: Conceptualization, X.C.; writing—original draft preparation, W.H.; writing-review and editing, G.M.

Funding: This work was supported by the National Social Science Foundation of China (16BJY180).

Conflicts of Interest: The authors declare no conflicts of interest.

\section{Appendix A}

Table A1. Variable definitions. R\&D—research and development.

\begin{tabular}{|c|c|c|c|c|}
\hline Variable Name & Variable Symbol & $\begin{array}{l}\text { Variable Value Method and Main } \\
\text { Specifications }\end{array}$ & Mean & SD \\
\hline Enterprise innovation & Innovat & Patent application quantity & 118.253 & 440.157 \\
\hline Returnee CEO & Ceosea & $\begin{array}{c}\text { Ceosea is " } 1 \text { " if a firm's CEO is a returnee } \\
\text { and " } 0 \text { " otherwise }\end{array}$ & $13.4 \%$ & \\
\hline Environmental uncertainty & $E U$ & $\begin{array}{l}\text { The coefficient of variation of sales over a } \\
\text { five-year period }\end{array}$ & 1.428 & 1.466 \\
\hline Firm ownership & Nature & $\begin{array}{c}\text { A dummy variable, } 1=\text { private enterprise, } \\
0=\text { others }\end{array}$ & $72.7 \%$ & \\
\hline CEO ownership & CEOshare & Shares CEO owns & $2.26 \mathrm{E} 7$ & 6.37E7 \\
\hline CEO gender & CEOgender & $1=$ male, $0=$ other & $96.5 \%$ & \\
\hline CEO duality & CEO duab & $\begin{array}{c}\text { A dummy variable that is equal to one if } \\
\text { the CEO is also the chairman and } \\
\text { zero otherwise }\end{array}$ & $89.20 \%$ & \\
\hline Returnee executive size & Sumforeitm & $\begin{array}{l}\text { The number of overseas executives in } \\
\text { the enterprise }\end{array}$ & 1.056 & 1.443 \\
\hline Board size & Mtbgm & Total number of directors & 18.141 & 4.299 \\
\hline Average age of the board & Tmtage & The directors' average age & 46.869 & 2.886 \\
\hline R\&D staff & Rdstaff & $\begin{array}{l}\text { The number ratio of the R\&D employees } \\
\text { to the total staff }\end{array}$ & 26.596 & 16.428 \\
\hline Ownership concentration & Concen & $\begin{array}{c}\text { Shareholding ratio of the } \\
\text { largest shareholder }\end{array}$ & $32.990 \%$ & 13.712 \\
\hline Enterprise age & Age & $\begin{array}{l}\text { The time between the initial creation of a } \\
\text { company and the present time (in years) }\end{array}$ & 14.872 & 5.343 \\
\hline Asset-liability ratio & Alr & The book value of total debt over assets & 33.634 & 18.816 \\
\hline Liquidity ratio & $A L$ & Current assets/total assets & 35.649 & 24.664 \\
\hline
\end{tabular}

\section{References}

1. Li, H.; Yan, Z.; Yu, L.; Zhou, L.A.; Zhang, W. Returnees Versus Locals: Who Perform Better in China's Technology Entrepreneurship? Strat. Entrep. J. 2012, 6, 257-272. [CrossRef]

2. Kenney, M.; Breznitz, D.; Murphree, M. Coming back home after the sun rises: Returnee entrepreneurs and growth of high tech industries. Res. Policy 2013, 42, 391-407. [CrossRef]

3. China Education Daily. Implementation of Overseas High-Level Talent Introduction Program. China Education Daily, 16 June 2009; 2. 
4. Luo, S.; Lovely, M.E.; Popp, D. Intellectual returnees as drivers of indigenous innovation: Evidence from the Chinese photovoltaic industry. World Econ. 2017, 40, 2424-2454. [CrossRef]

5. Prashantham, S.; Eranova, M.; Couper, C. Globalization, entrepreneurship and paradox thinking. Asia Pac. J. Manag. 2018, 35, 1-9. [CrossRef]

6. Batjargal, B. Internet entrepreneurship: Social capital, human capital, and performance of Internet ventures in China. Res. Policy 2007, 36, 605-618. [CrossRef]

7. Liu, X.; Lu, J.; Filatotchev, I.; Buck, T.; Wright, M. Returnee entrepreneurs, knowledge spillovers and innovation in high-tech firms in emerging economies. J. Int. Bus. Stud. 2009, 41, 1183-1197. [CrossRef]

8. McEvily, B.; Jaffee, J.; Tortoriello, M. Not All Bridging Ties Are Equal: Network Imprinting and Firm Growth in the Nashville Legal Industry, 1933-1978. Organ. Sci. 2012, 23, 547-563. [CrossRef]

9. Qin, F.; Wright, M.; Gao, J. Are 'sea turtles' slower? Returnee entrepreneurs, venture resources and speed of entrepreneurial entry. J. Bus. Venturing 2017, 32, 694-706. [CrossRef]

10. Fu, X.; Hou, J.; Sanfilippo, M. Highly skilled returnees and the internationalization of EMNEs: Firm level evidence from China. Int. Bus. Rev. 2017, 26, 579-591. [CrossRef]

11. Lin, D.; Lu, J.; Liu, X.; Choi, S.J. Returnee CEO and innovation in Chinese high-tech SMEs. Int. J. Technol. Manag. 2014, 65, 151-171. [CrossRef]

12. Lin, Y.; Chen, C.; Lin, B. The dual-edged role of returnee board members in new venture performance. J. Bus. Res. 2017, 90, 347-358. [CrossRef]

13. Chen, J.; Sharma, P.; Zhan, W.; Liu, L. Demystifying the impact of CEO transformational leadership on firm performance: Interactive roles of exploratory innovation and environmental uncertainty. J. Bus. Res. 2019, 96, 85-96. [CrossRef]

14. Waldman, D.A.; Ramirez, G.G.; House, R.J.; Puranam, P. Does leadership matter_CEO leadership attributes and profitability under conditions of perceived environmental uncertainty. Acad. Manage. J. 2001, 44, 134-143. [CrossRef]

15. Carpenter, M.A.; Fredrickson, J.W. Top management teams, global strategic posture, and the moderating role of uncertainty. Acad. Manage. J. 2001, 44, 533-546. [CrossRef]

16. Richard, O.C.; Murthi, B.P.S.; Ismail, K. The impact of racial diversity on intermediate and long-term performance: The moderating role of environmental context. Strat. Manag. J. 2007, 28, 1213-1233. [CrossRef]

17. Li, P.-Y.; Lo, F.-Y. Top management teams' managerial resources and international diversification. Manage. Decis. 2017, 55, 1999-2017. [CrossRef]

18. Finkelstein, S.; Hambrick, D.; Cannella, A.A. Strategic Leadership: Theory and Research on Executives, Top Management Teams and Boards; Oxford University Press: New York, NY, USA, 2009.

19. Agle, B.R.; Nagarajan, N.J.; Sonnenfeld, J.A.; Srinivasan, D. Does Ceo Charisma Matter? An Empirical Analysis Of The Relationships Among Organizational Performance, Environmental Uncertainty, And Top Management Team Perceptions Of CEO Charisma. Acad. Manag. J. 2006, 49, 161-174. [CrossRef]

20. Henry, C. Investment decisions under uncertainty: The "irreversibility effect". Am. Econ. Rev. 1974, 64, 1006-1012. [CrossRef]

21. Oke, A.; Walumbwa, F.O.; Myer, A. Innovation Strategy, Human Resource Policy, and Firms' Revenue Growth_The Roles of Environmental Uncertainty and Innovation Performance. Decis. Sci. 2012, 43, $273-302$. [CrossRef]

22. Jansen, J.J.P.; Vera, D.; Crossan, M. Strategic leadership for exploration and exploitation: The moderating role of environmental dynamism. Leadership Quart. 2009, 20, 5-18. [CrossRef]

23. Wright, B.D. Changing intellectual property regimes: Implications for developing country agriculture. Int. J. Technol. Global. 2006, 2, 93. [CrossRef]

24. Marquis, C.; Tilcsik, A. Imprinting: Toward a Multilevel Theory. Acad. Manag. Ann. 2013, 7, 195-245. [CrossRef]

25. Yuan, R.; Wen, W. Managerial foreign experience and corporate innovation. Soc. Sci. Electron. Publ. 2018, 48, 752-770. [CrossRef]

26. Jones, R.C. The Local Economic Imprint of Return Migrants in Bolivia. Popul. Space Place 2011, 17, $435-453$. [CrossRef]

27. Thomas, N.M.; Kashiramka, S.; Yadav, S.S. Dynamic Linkages among Developed, Emerging and Frontier Capital Markets of Asia Pacific region. J. Adv. Manag. Res. 2017, 14, 332-351. [CrossRef] 
28. Risso, W.A. The informational efficiency: The emerging markets versus the developed markets. Appl. Econ. Lett. 2009, 16, 485-487. [CrossRef]

29. Zhou, Y.U.; Hsu, J.Y. Divergent engagements: Roles and strategies of taiwanese and mainland chinese returnee entrepreneurs in the it industry. Global Networks 2011, 11, 398-419. [CrossRef]

30. Halinen, A.; Jaakkola, E.; Rusanen, H. Accessing resources for service innovation-The critical role of network relationships. J. Serv. Manag. 2014, 45, 223-225. [CrossRef]

31. Luo, P.Y. Managerial ties and firm performance in a transition economy: The nature of a micro-macro link. Acad. Manag. J. 2000, 43, 486-501. [CrossRef]

32. Cravens, D.W.; Piercy, N.F.; Baldauf, A. Management framework guiding strategic thinking in rapidly changing markets. J. Mark. Manag. 2009, 25, 31-49. [CrossRef]

33. Chen, F.-W.; Lin, M.-X.; Wang, T. Sustainable Resource Acquisition Path: A Dynamic Model of Embedded Entrepreneurial Network Governance under Uncertainty. Sustainability 2018, 10, 4061. [CrossRef]

34. Kaplan, S. Framing Contests: Strategy Making Under Uncertainty. Organ. Sci. 2008, 19, 729-752. [CrossRef]

35. Hurlbert, J.S.; Haines, V.A.; Beggs, J.J. Core Networks and Tie Activation: What Kinds of Routine Networks Allocate Resources in Nonroutine Situations? Am. Soc. Rev. 2000, 65, 598-618. [CrossRef]

36. Mason, D.J. An Apple a Day: We have limited resources for prevention. Are we using them wisely? Am. J. Nurs. 2001, 101, 7. [CrossRef] [PubMed]

37. Hansen, B.E. Threshold effects in non-dynamic panels: Estimation, testing and inference. J. Econom. 1999, 93, 345-368. [CrossRef]

38. Alaabed, A.; Masih, M. Finance-growth nexus: Insights from an application of threshold regression model to Malaysia's dual financial system. Borsa Istanbul Rev. 2016, 16, 63-71. [CrossRef]

39. Chen, J.; Quang, T. The impact of international financial integration on economic growth: New evidence on threshold effects. Econ. Model. 2014, 42, 475-489. [CrossRef]

40. Salomon, R.M.; Shaver, J.M. Learning by Exporting: New Insights from Examining Firm Innovation. J. Econ. Manag. Strat. 2010, 14, 431-460. [CrossRef]

41. Wen, J.; Yang, D.; Feng, G.-F.; Dong, M.; Chang, C.-P. Venture capital and innovation in China: The non-linear evidence. Struct. Change Econ. D. 2018, 46, 148-162. [CrossRef]

42. Blundell, R.; Joyce, R.; Keiller, A.N.; Ziliak, J.P. Income inequality and the labour market in Britain and the US. J. Public Econ. 2018, 162, 48-62. [CrossRef]

43. Ghosh, D.; Olsen, L. Environmental uncertainty and managers' use of discretionary accruals. Account. Organ. Soc. 2009, 34, 188-205. [CrossRef]

44. Haider, Z.A.; Liu, M.; Wang, Y.; Zhang, Y. Government ownership, financial constraint, corruption, and corporate performance: International evidence. J. Int. Financ. Mark. I 2018, 53, 76-93. [CrossRef]

45. Kieschnick, R.; Moussawi, R. Firm age, corporate governance, and capital structure choices. J. Corp. Financ. 2018, 48, 597-614. [CrossRef]

46. Francis, B.; Hasan, I.; Wu, Q. Professors in the Boardroom and Their Impact on Corporate Governance and Firm Performance. Financ. Manag. 2015, 44, 547-581. [CrossRef]

47. Sambharya, R.B. Foreign experience of top management teams and international diversification strategies of US multinational corporations. Strat. Manag. J. 1996, 17, 739-746. [CrossRef]

48. Harris, R.D.F.; Tzavalis, E. Inference for unit roots in dynamic panels where the time dimension is fixed. J. Econ. 1999, 91, 201-226. [CrossRef]

49. Pao, H.-T.; Tsai, C.-M. Multivariate Granger causality between CO2 emissions, energy consumption, FDI (foreign direct investment) and GDP (gross domestic product): Evidence from a panel of BRIC (Brazil, Russian Federation, India, and China) countries. Energy 2011, 36, 685-693. [CrossRef]

50. Su, Y.; An, X.-L. Application of threshold regression analysis to study the impact of regional technological innovation level on sustainable development. Renew. Sust. Energy Rev. 2018, 89, 27-32. [CrossRef]

51. Shah, D. Dwindling Viability of PACS During Period of Institutional Reforms. SSRN Electron. J. 2007, 247, 215-232. [CrossRef]

52. Zhang, J.; Cheng, L. Threshold Effect of Tourism Development on Economic Growth Following a Disaster Shock: Evidence from the Wenchuan Earthquake, P.R. China. Sustainability 2019, 11, 371. [CrossRef]

53. Szkudlarek, B. Reentry-A review of the literature. Int. J. Intercult. Rel. 2010, 34, 1-21. [CrossRef]

54. Liu, X.; Lu, J.; Choi, S.J. Bridging Knowledge Gaps: Returnees and Reverse Knowledge Spillovers from Chinese Local Firms to Foreign Firms. Manag. Int. Rev. 2014, 54, 253-276. [CrossRef] 
55. Lee, J.H.; Roberts, M.J.D. International returnees as outside directors: A catalyst for strategic adaptation under institutional pressure. Int. Bus. Rev. 2015, 24, 594-604. [CrossRef]

56. Jian, Z.; Kong, D.; Ji, W. Doing Good Business by Hiring Directors with Foreign Experience. J. Bus. Ethics 2015, 153, 1-18. [CrossRef]

57. McHenry, J.E.H.; Welch, D.E. Entrepreneurs and internationalization: A study of Western immigrants in an emerging market. Int. Bus. Rev. 2018, 27, 93-101. [CrossRef]

58. Kunisch, S.; Menz, M.; Cannella, A.A. The CEO as a key microfoundation of global strategy: T ask demands, CEO origin, and the CEO's international background. Int. Bus. Rev. 2019, 9, 19-41. [CrossRef]

59. Wang, H.; Zweig, D.; Lin, X. Returnee Entrepreneurs: Impact on China's globalization process. J. Contemp. China 2011, 20, 413-431. [CrossRef]

60. Chen, Y.C. The limits of Brain circulation: Chinese returnees and technological development in Beijing. Pac. Aff. 2008, 81, 195-215. [CrossRef]

(C) 2019 by the authors. Licensee MDPI, Basel, Switzerland. This article is an open access article distributed under the terms and conditions of the Creative Commons Attribution (CC BY) license (http://creativecommons.org/licenses/by/4.0/). 